\title{
How far and how old: Longevity and displacement records from the South African Bird Ringing Scheme for Ardeidae, Threskiornithidae and Ciconiidae
}

\begin{tabular}{|c|c|}
\hline \multicolumn{2}{|c|}{$\begin{array}{l}\text { Authors: } \\
\text { Sanjo Rose }{ }^{1} \\
\text { Hans-Dieter Oschadleus }^{2,3} \\
\text { Dane Paijmans }{ }^{1} \text { (D) }\end{array}$} \\
\hline \multicolumn{2}{|c|}{$\begin{array}{l}\text { Affiliations: } \\
{ }^{1} \text { FitzPatrick Institute of African } \\
\text { Ornithology, DST-NRF Centre } \\
\text { of Excellence, University of } \\
\text { Cape Town, South Africa }\end{array}$} \\
\hline \multicolumn{2}{|c|}{$\begin{array}{l}{ }^{2} \text { Animal Demography Unit, } \\
\text { Department of Biological } \\
\text { Sciences, University of } \\
\text { Cape Town, South Africa }\end{array}$} \\
\hline $\begin{array}{l}{ }^{3} \text { School of Life } \\
\text { University of } k \\
\text { South Africa }\end{array}$ & $\begin{array}{l}\text { Sciences, } \\
\text { waZulu-Natal, }\end{array}$ \\
\hline \multicolumn{2}{|c|}{$\begin{array}{l}\text { Corresponding author: } \\
\text { Sanjo Rose, } \\
\text { sanjojenkins@gmail.com }\end{array}$} \\
\hline \multicolumn{2}{|c|}{$\begin{array}{l}\text { Dates: } \\
\text { Received: } 07 \text { Dec. } 2017 \\
\text { Accepted: } 22 \text { Aug. } 2018 \\
\text { Published: } 15 \text { Jan. } 2019\end{array}$} \\
\hline \multicolumn{2}{|c|}{$\begin{array}{l}\text { How to cite this article: } \\
\text { Rose, S., Oschadleus, H-D. \& } \\
\text { Paijmans, D., 2019, 'How far } \\
\text { and how old: Longevity and } \\
\text { displacement records from } \\
\text { the South African Bird } \\
\text { Ringing Scheme for Ardeidae, } \\
\text { Threskiornithidae and } \\
\text { Ciconiidae', Bothalia 49(1), } \\
\text { a2333. https://doi.org/ } \\
\text { 10.4102/abc.v49i1.2333 }\end{array}$} \\
\hline \multicolumn{2}{|c|}{$\begin{array}{l}\text { Copyright: } \\
\text { (C) 2019. The Authors. } \\
\text { Licensee: AOSIS. This } \\
\text { is licensed under the } \\
\text { Creative Commons } \\
\text { Attribution License. }\end{array}$} \\
\hline \multicolumn{2}{|l|}{ Read online: } \\
\hline 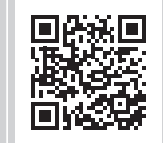 & $\begin{array}{l}\text { Scan this QR } \\
\text { code with your } \\
\text { smart phone or } \\
\text { mobile device } \\
\text { to read online. }\end{array}$ \\
\hline
\end{tabular}

Background: Understanding the movement and displacement of individuals within avian species is important for conservation. Herons, Storks and Egrets are especially important as they are migratory species and are potential indicator species. It is therefore valuable to set life history baselines to understand survival.

Objectives: To establish baseline longevity and displacement values for the avian families Ardeidae, Threskiornithidae and Ciconiidae using the South African Bird Ringing Scheme (SAFRING) data for Africa and to highlight gaps in the SAFRING database for these families.

Method: We used data archives of ringed and subsequently reported individuals to determine maximum displacement and longevities from the past seven decades for each species within these three families. Displacement was estimated by the straight-line distance between subsequent records for the same individual. Longevity is the measure of time elapsed in records for the same individual.

Results: Displacement and longevity data were available for 17 of the 24 species in the focus families. Individuals of most of the species were ringed as nestlings so displacement records may represent dispersal. Displacement ranged from a maximum of $10114 \mathrm{~km}$ for a White Stork (Ciconia ciconia) to $2.5 \mathrm{~km}$ for a Little Bittern (Ixobrychus minutus). Several species are poorly sampled, resulting in longevity records of just a few days. Despite that, longevity values were $>5$ years for 16 species, and the highest value was 25.3 years for a White Stork.

Conclusion: It was possible to determine longevity values for most of the species within the three families investigated. Based on the displacement profiles for species with sufficient records, there are large differences in movement between species. Certain common species such as Purple Heron (Ardea purpurea) have very few ringing records, which indicate a need for further species-specific research as the longevity values are not representative. This could greatly benefit studies aiming to use these species as ecosystem health indicators as well as identify which species are at risk.

\section{Introduction}

The families Ardeidae, Threskiornithidae and Ciconiidae are small to large birds, typically associated with wetland habitats. Some species migrate whilst others are resident with most species being nomadic to some extent, following rainfall patterns and seasonal habitat distribution (Hockey et al. 2005). This adaptable group, with species that have large global distributions, can colonise novel and anthropogenically altered environments. Nest site flexibility in White Storks (Ciconia ciconia), for example, has enabled them to utilise urban chimneys and telephone poles (Tryjanowski et al. 2008).

Understanding avian dispersal, migration and survival is crucial for species conservation as it informs which members of the population are most vulnerable and helps identify important nesting, feeding and resting locations. This is particularly important as globally certain historical migration behaviours are changing, driven by factors such as altered food sources (Rotics et al. 2017), earlier onset of spring (Jenni \& Kery 2003) and rapid land alteration (Lemoine et al. 2007). For example, a recent study found that some juveniles of the White Stork are opting to remain in Europe, closer to their natal grounds, as they can exploit the open-air dumps (Rotics et al. 2017). This has important implications for land-use management practices if these storks are to be protected.

In the past few decades dispersal has been widely studied either through Global Positioning System or satellite tracking (e.g. Berthold et al. 2002; Chevallier et al. 2011; Rotics et al. 2017; Van der 
Winden, Poot \& Van Horssen 2010). Although highly effective, this method can be costly, which constrains sample sizes. Ringing is an alternative, less costly method. It is cruder, only indicating the initial and final location; however, it is still very useful, and several studies still use it for dispersal analysis (e.g. Bartolome 1996, Little Egrets [Egretta garzetta] in Spain; Fasola et al. 2002, Little Egrets in France).

Here we summarise seven decades of data from the South African Bird Ringing Scheme's (SAFRING) database on displacement and longevity for the families Threskiornithidae, Ardeidae and Ciconiidae. Although a few single-species studies have been published with respect to dispersal and longevity in these families (Kopij 2017, Cattle Egret [Bubulcus ibis], Clark \& Clark 1979, African Sacred Ibis, [Threskiornis aethiopicus]), a broader assessment of the species is lacking. Such an assessment will identify gaps in the data and provide insights into where further research could be focused and could clarify whether or not movement is dispersal or migration by noting age at ringing and subsequent records.

\section{Methods}

The ringing, recapture, resighting and recovery records of Ardeidae, Threskiornithidae and Ciconiidae were extracted from the SAFRING database in October 2017. Twenty-four species in these families that occur in southern Africa were included in the assessment. From these data the maximum displacement and longevity values were determined. Maximum displacement was calculated as the greatest direct distance (in kilometres) between the initial ringing and subsequent reporting for an individual. To understand if displacement represents postnatal dispersal or migration, the age associated with the records was noted. Longevity is the time elapsed between date of ringing and final subsequent report for the individual. Consequently, longevity values are minimum values. All maximum records were verified by the original reports submitted to SAFRING. Records noted as only 'rings found' or well-decomposed carcass found, were not used because of the uncertainty of the date of death.

The final data set included some records of birds originally ringed in Europe. Location of ringing is indicated in the 'ring number' column of Table 1 by the country name in brackets. To give an indication of how many ringed individuals were re-recorded, a reporting rate was calculated for each species. This rate is simply the percentage of initial ringing records reported at least once (distinct records) after the ringing event. A high percentage would indicate that ringed birds of a particular species are likely to be located at a later point. Many of the secondary records for the three families do not clearly state whether records are resightings or retraps. As these species are rarely retrapped, most of these secondary records are probably resightings.

Displacement profiles were generated for those species with more than 100 subsequent reports (retraps, resightings and recoveries) to investigate the distance moved by individuals at a finer level. These included the African Sacred Ibis, Hadeda Ibis (Bostrychia hagedash), Black-headed Heron (Ardea melanocephala) and Cattle Egret. As a result of a limited number of adult initial records, only records where the initial report involved pulli (nestlings, chicks ringed in the nest) and juvenile birds were used for the profiles.

\section{Results}

A total of 29842 records (26 651 initial, and 3191 records made up of retraps, resightings and recoveries) were reported for all 24 species within Ardeidae, Threskiornithidae and Ciconiidae (Table 1). Black-headed Heron, Cattle Egret, White Stork, African Sacred Ibis and Hadeda Ibis are the most ringed species, with over 1000 ringing records each (Table 1). Species with no subsequent records were Slaty Egret (Egretta vinaceigula), Little Blue Heron (Egretta caerulea), Dwarf Bittern (Ixobrychus sturmii), White-backed Nightheron (Gorsachius leuconotus), Eurasian Bittern (Botaurus stellaris), Saddle-billed Stork (Ephippiorhynchus senegalensis) and Yellow-billed Stork (Mycteria ibis) and as a result no displacements or longevities could be calculated (Table 1).

The greatest distances travelled were $10114 \mathrm{~km}$ for White Stork, $4233 \mathrm{~km}$ for Cattle Egret and $1465 \mathrm{~km}$ for African Sacred Ibis (Table 1). The species for which the smallest maximum displacement was measured $(2.5 \mathrm{~km})$ was the Little Bittern (Ixobrychus minutus) (Table 1). Longevity records of $>5$ years exist for 16 species, with the maximum longevity being 25.3 years (White Stork) (Table 1 ).

Most initial records were pulli or chicks and juveniles (90.3\%, $n=24$ 070) with the remainder listed as either 'unknown' or adults (9.7\%) (Appendix 1 and 2). For Saddlebilled Stork, Black Heron (Egretta ardesiaca), Abdim's Stork (Ciconia abdimii), Dwarf Bittern, Squacco Heron (Ardeola ralloides), Green-backed Heron (Butorides striata), Little Bittern and Hadada Ibis, most individuals ringed were recorded as adults (Appendix 1 and 2).

Most Ardeidae and Threskiornithidae chicks were reported again close $(<50 \mathrm{~km})$ to the original ringing site. $90.4 \%$ of the displacement records for storks were over $500 \mathrm{~km}$. For individuals reported dead, $28.2 \%$ had known finding details: sick or injured subsequently died (17.5\%), shot $(16.8 \%)$, collision (fence, line or wire) $(15.6 \%)$, victim of weather $(5.1 \%)$, killed or attacked by bird $(4.3 \%)$ and electrocuted (2.9\%).

\section{Discussion}

This study attempted to provide maximum longevity and displacement values for the 24 species of Ardeidae, Threskiornithidae and Ciconiidae occurring in southern Africa. Longevity data were available for 17 species (see Appendix 2 for top three values). In addition, this study updated some of the data published in Underhill et al. (1999). For example, longevity values for two species were updated: Green-backed Heron (0-12 years) and Hadeda Ibis (5-10 years). 
TABLE 1: Maximum longevity and displacement records of southern African Ardeidae, Threskiornithidae and Ciconiidae species from ringing records of the South African Bird Ringing Scheme.

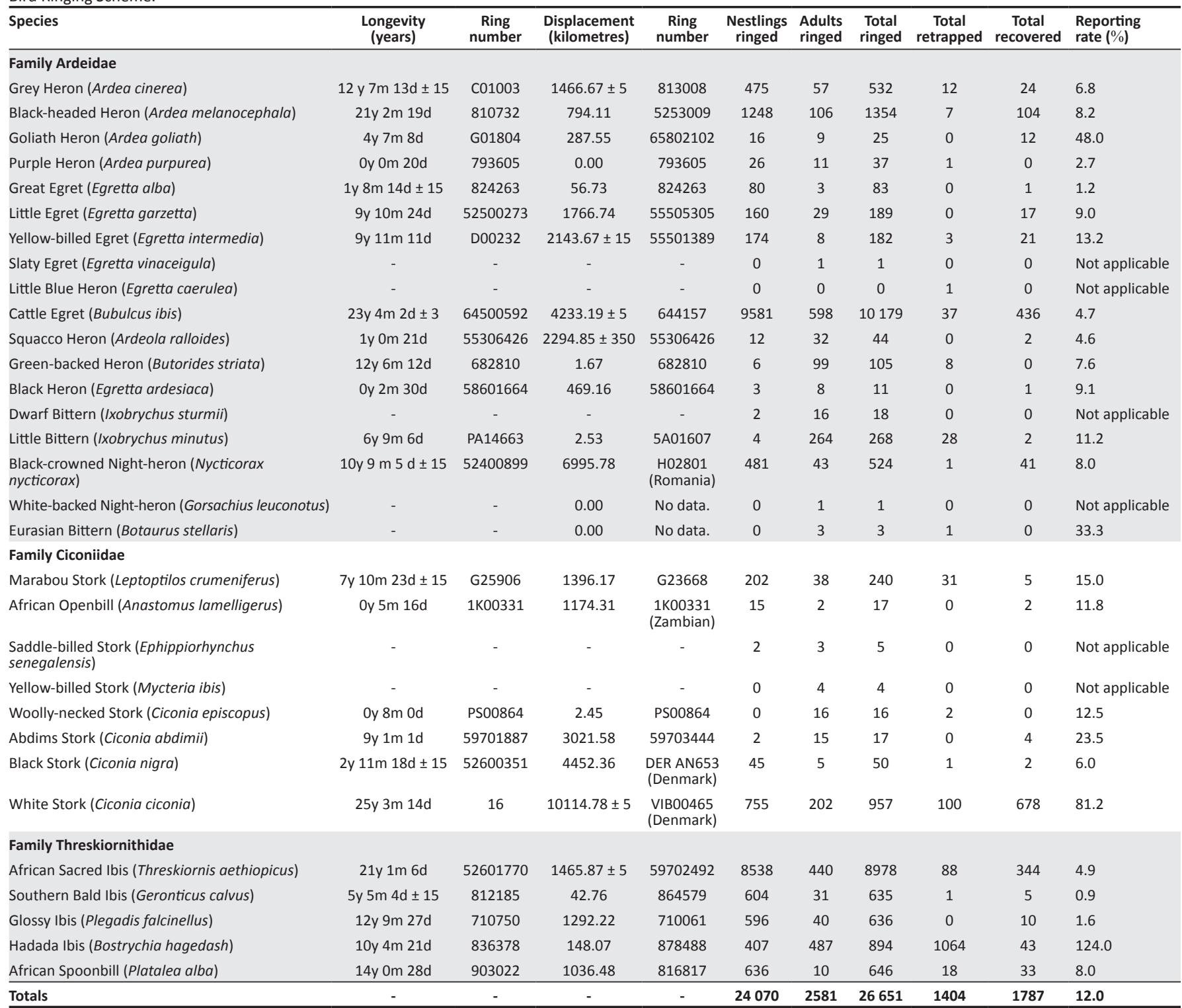

Note: Values displaying a \pm symbol indicate level of uncertainty in days as exact date or location was not known. Records belonging to foreign schemes are indicated in the ring number column in brackets. Reporting rate is a percentage of ringed individuals located again as retraps, resightings or recoveries.

Most individuals for all species were ringed as chicks, with very few ringing records for adults, so it was not possible to investigate the relationship between age and displacement. The lack of ringing records for adult individuals could well be explained by their large size, which makes these species difficult to trap in mistnets. As most ringers in southern Africa are hobbyists who typically use mistnetting, members of the Ardeidae, Threskiornithidae and Ciconiidae are rarely caught. Species in Ciconiidae have high European ringing totals but they were also ringed mainly as chicks. Bittern species are also difficult to locate, resulting in few casual ringing events. As some species in these families, such as Little Egret and Grey Heron, are common, it would be beneficial to establish baseline data sets for them to use as indicators of ecosystem health changes such as has been done elsewhere.

There is some evidence for movement of pulli in all three families based on displacement records (Table 1). As the data are biased towards ringed chicks, with poor adult representation it was not possible to determine whether the dispersal of young birds represents postnatal dispersal or migration. Puglisi and Bretagnolle (2005) found that Great Bittern chicks from sites in Italy and France moved at most $5.5 \mathrm{~km}$ from a nest, which they argued was far given that the average distance between nests measured at two sites was $148 \mathrm{~m}$ and $149 \mathrm{~m}$. This suggests that the scale of dispersal could be very small in some species. In a southern African context, little is known about the migration or movement of many species in the three families, with the exception of those in the family Ciconiidae, which are known to migrate large distances. Some movement traits are known in the same species occurring in Europe, for example overwintering Eurasian Bitterns in England have been noted to return to the same wetland (Gilbert, Tyler \& Smith 2005). For species like the Purple Heron, the picture appears to be complex. Although Palearctic migrants make it to 
North and West Africa (Van der Winden et al. 2010), there is no evidence to suggest that they migrate to southern Africa (Hockey et al. 2005; Martin 1997).

The displacement profiles generated were unsurprising (Figure 1); Hadeda Ibis are known not to migrate as a rule although young may disperse (Skead 1951). The high number of chicks recovered less than $5 \mathrm{~km}$ from the site of ringing in African Sacred Ibis could represent pulli that die at a colonial nesting site. There is a clear indication of some movement of Cattle Egret in Figure 1, which supports the knowledge that this species does not regularly migrate, although it may track seasonal rainfall (Hockey et al. 2005). Juvenile Egrets may disperse short distances from the nesting roost whilst foraging although tracking of individual birds will provide a clearer picture. No clear pattern emerged for the Blackheaded Heron, although few travelled more than $500 \mathrm{~km}$.
The increase in urban populations of some species such as Sacred Ibis and Hadeda Ibis has raised concerns about noise and water pollution. As a result, various efforts are made to control or cull populations, such as egg-oiling in Australia (Martin et al. 2007). For these methods to be effective and managed responsibly, the life history of these birds needs to be well understood. It is also important to establish which range changes are caused by direct human intervention and which are 'natural' in response to habitat change.

Where longevity data do exist, individuals in several species such as Grey Heron, Black-headed Heron and Cattle Egret appear to be long-lived, which justifies the effort in trapping, ringing and monitoring. Many of the species included in the study are also found in Europe, where intensive ringing programmes have been operating since the early 1900s. Greater ringing effort over a longer period of time seems to
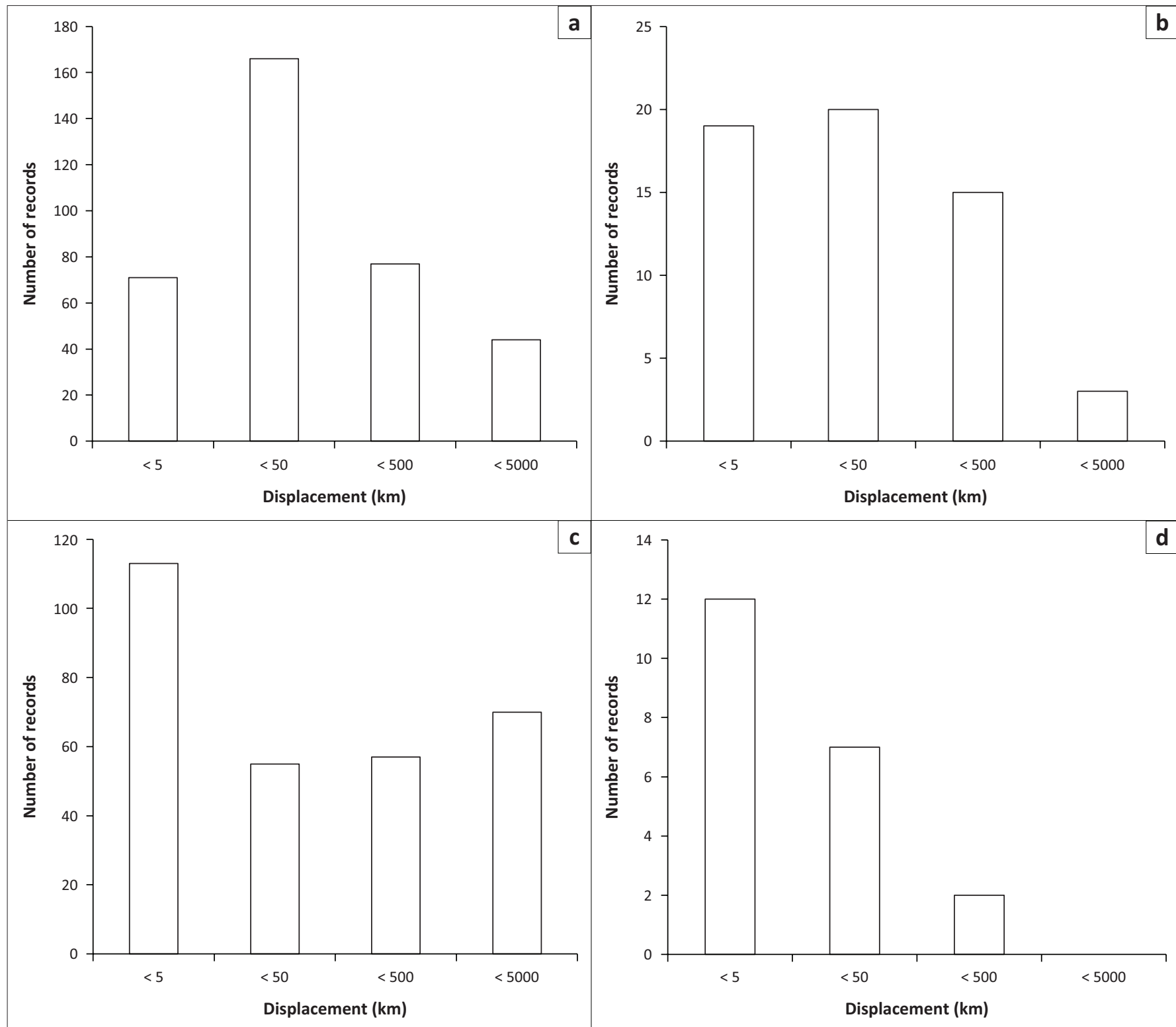

$\mathrm{km}$, kilometres.

FIGURE 1: Number of (a) Cattle Egrets (Bubulcus ibis), (b) Black-headed heron (Ardea melanocephala), (c) Sacred Ibis (Threskiornis aethiopicus) and (d) Hadeda Ibis (Bostrychia hagedash) trapped, sighted or recovered having travelled $1 \mathrm{~km}-5 \mathrm{~km}, 6 \mathrm{~km}-50 \mathrm{~km}, 51 \mathrm{~km}-500 \mathrm{~km}$ and $501 \mathrm{~km}-5000 \mathrm{~km}$, after being ringed as pulli or juveniles. These four species were selected based on having sufficient records to generate these figures. 
have translated into greater longevities in many instances and in several species, long lifespans have been recorded where no reasonable value exists in the SAFRING data. For example, European data for Purple Heron gives longevity as 25 year 5 months, for Squacco Heron as 5 year 10 months, for Eurasian Bittern as > 11 years 4 months and for Black Stork as 18 years 7 months (Fransson et al. 2010). Only one species, the Cattle Egret, has a greater value in South Africa of 23 year 4 months (Table 1) compared to the European value of 18 years 5 months (Fransson et al. 2010). Cattle Egrets in South Africa were the focus of an intense effort to ring many individuals in the 1970s, indicating that dedicated projects could deliver worthwhile data.

\section{Conclusion}

Using ringing data from SAFRING, longevity and displacement values are presented for avian families Ardeidae, Threskiornithidae and Ciconiidae. Longevity data exist for 17 of the 24 species, although some of the values are not realistic because of poor sample sizes. The data set is biased towards juvenile and chick data, which leaves many questions around adult movement and longevity unanswered. Dedicated research is required to better understand the basic biology of species in the three families as well as how these species are responding to land use and climate change.

\section{Acknowledgements}

We wish to thank all SAFRING ringers for submitting their ringing data to SAFRING. A special note of thanks too to the foreign schemes who provided data where necessary. At the time of submission, S.R. was supported by the National Research Foundation-Department of Science and Technology. We also thank all the reviewers who provided valuable inputs and suggestions.

\section{Competing interests}

The authors declare that they have no financial or personal relationships that may have inappropriately influenced them in writing this article.

\section{Authors' contributions}

The motivation for the study was initiated by all authors. D.P. did most of the data extraction and analysis. S.R. did most of the data verification. S.R. wrote the bulk of the manuscript. H-D.O. assisted with the entire process.

\section{References}

Bartolome, J., Fernandez-Cruz, M. \& Campos, F., 1996, 'Band recoveries of Spanish little egrets, Egretta garzetta', Colonial Waterbirds 19, 220-225. https://doi. org $/ 10.2307 / 1521859$

Berthold, P., Bossche, W.V.D., Jakubiec, Z., Kaatz, C., Kaatz, M. \& Querner, U., 2002, 'Long-term satellite tracking sheds light upon variable migration strategies of White Storks (Ciconia ciconia)', Journal für Ornithologie 143, 489-493. https://doi. org/10.1007/BF02465604

Chevallier, D., Le Maho, Y., Brossault, P., Baillon, F. \& Massemin, S., 2011, 'The use of stopover sites by Black Storks (Ciconia nigra) migrating between West Europe and West Africa as revealed by satellite telemetry', Journal of Ornithology 152, 1-13. https://doi.org/10.1007/s10336-010-0536-6

Clark, R.A. \& Clark, A., 1979, 'Daily and seasonal movements of the sacred ibis at Pretoria, Transvaal', Ostrich 50, 94-103.

Fasola, M., Hafner, H., Kayser, Y., Bennetts, R.E. \& Cezilly, F., 2002, 'Individual dispersal among colonies of Little Egrets Egretta garzetta', lbis 144, 192-199. https://doi. org/10.1046/j.1474-919X.2002.00060.x

Fransson, T., Kolehmainen, T., Kroon, C., Jansson, L. \& Wenninger, T., 2010, EURING list of longevity records for European birds, viewed 14 November 2017, from https:// euring.org/data-and-codes/longevity-list.

Gilbert, G., Tyler, G. \& Smith, K.W., 2005, 'Behaviour, home-range size and habitat use by male Great Bittern Botaurus stellaris in Britain', Ibis 147, 533-543. https://doi. org/10.1111/j.1474-919x.2005.00424.x

Hockey, P., Dean, W. \& Ryan, P., (eds.), 2005, Roberts birds of Southern Africa, 7th edn., The Trustees of the John Voelcker Bird Book Fund, Cape Town, South Africa.

Jenni, L. \& Kéry, M., 2003, 'Timing of autumn bird migration under climate change: Advances in long-distance migrants, delays in short-distance migrants' Proceedings of the Royal Society B: Biological Sciences 270, 1467-1471. https:// doi.org/10.1098/rspb.2003.2394

Kopij, G., 2017, 'Migratory connectivity of South African Cattle Egrets (Bubulcus ibis, Ciconiiformes, Ardeidae)', Zoological Journal 96, 418-428. https://doi.org/10.7868/ S0044513417040079

Lemoine, N., Bauer, H., Peintinger, M. \& Bohning-Gaese, K., 2007, 'Effects of climate and land-use change on species abundance in a Central European bird community', Conservation Biology 21, 495-503. https://doi.org/10.1111/j.1523-1739.2006. 00633.x

Martin, A.P., 1997, 'Purple Heron', in J.A. Harrison, D.G. Allan, L.G. Underhill, M. Herremans, A.J. Tree, V. Parker et al. (eds.), The Atlas of Southern African Birds, vol. 1, p. 48, BirdLife South Africa, Johannesburg.

Martin, J.M., French, K. \& Major, R.E., 2007, 'The pest status of Australian white ibis (Threskiornis molucca) in urban situations and the effectiveness of egg-oil in reproductive control', Wildlife Research 34, 319-324. https://doi.org/10.1071/ WR07005

Puglisi, L. \& Bretagnolle, V., 2005, 'Breeding biology of the Great Bittern', Waterbirds: The International Journal of Waterbird Biology 28, 392-398. https://doi.org/ 10.1675/1524-4695(2005)028[0392:BBOTGB]2.0.CO;2

Rotics, S., Turjeman, S., Kaatz, M., Resheff, Y.S., Zurell, D., Sapir, N. et al., 2017 , 'Wintering in Europe instead of Africa enhances juvenile survival in a long-distance migrant', Animal Behaviour 126, 79-88. https://doi.org/10.1016/j.anbehav.2017. 01.016

Skead, C.J., 1951, 'A study of the Hadedah Ibis Hagedashiah hagedash', Ibis 93 , 360-382. https://doi.org/10.1111/j.1474-919X.1951.tb05440.x

Tryjanowski, P., Kosicki, J.Z., Kuźniak, S. \& Sparks, T.H., 2008, 'Long-term changes and breeding success in relation to nesting structures used by the White Stork, Ciconia ciconia', Annales Zoologici Fennici 46, 34-38. https://doi.org/10.5735/086. 046.0104

Underhill, L.G., Tree, A.J., Oschadleus, H.D. \& Parker, V., 1999, Review of ring recoveries of Waterbirds in Southern Africa, Avian Demography Unit, University of Cape Town, Cape Town.

Van der Winden, J., Poot, M.J.M. \& Van Horssen, P.W., 2010, 'Large birds can migrate fast: The post-breeding flight of the Purple Heron Ardea purpurea to the Sahel', Ardea 98, 395-402. https://doi.org/10.5253/078.098.0313 


\section{Appendix 1}

TABLE 1-A1: Top three displacement records of southern African Ardeidae, Threskiornithidae and Ciconiidae species from ringing records from the South African Ringing Scheme.

\begin{tabular}{|c|c|c|c|c|c|c|c|c|}
\hline Family & Species & $\begin{array}{l}\text { Displacement } \\
\text { (kilometres) }\end{array}$ & $\begin{array}{l}\text { Initial } \\
\text { Coord. }\end{array}$ & $\begin{array}{l}\text { Second } \\
\text { Coord. }\end{array}$ & Ring number & Initial age & $\begin{array}{l}\text { Secondary } \\
\text { age }\end{array}$ & Sex \\
\hline \multirow[t]{30}{*}{ Ardeidae } & \multirow[t]{3}{*}{ Grey Heron (Ardea cinerea) } & $1466.67 \pm 5$ & 1850S1650E & $3035 S 2327 E$ & 813008 & Pullus & Unknown & Unknown \\
\hline & & $1224.33 \pm 5$ & 1850S1650E & 2833S2230E & 813058 & Pullus & Juvenile & Unknown \\
\hline & & 530.64 & 1550 S2721E & 2035S2750E & 1K0137 & Pullus & Juvenile & Unknown \\
\hline & \multirow[t]{3}{*}{ Black-headed Heron (Ardea melanocephala) } & 797.55 & $2610 S 2818 \mathrm{E}$ & $2012 S 3238 E$ & 52503009 & Pullus & Unknown & Unknown \\
\hline & & $694.43 \pm 5$ & $2610 S 2818 \mathrm{E}$ & $322352737 \mathrm{E}$ & 810878 & Pullus & Unknown & Unknown \\
\hline & & 670.00 & $2611 S 2826 \mathrm{E}$ & $313952532 \mathrm{E}$ & 5253962 & Juvenile & Juvenile & Unknown \\
\hline & \multirow[t]{3}{*}{ Goliath Heron (Ardea goliath) } & 287.55 & 2633S2536E & $290852528 \mathrm{E}$ & 65802102 & Pullus & Juvenile & Unknown \\
\hline & & 186.61 & $2551 S 2718 \mathrm{E}$ & $2633 S 2536 \mathrm{E}$ & 65802041 & Unknown & Unknown & Unknown \\
\hline & & 182.24 & $1900 S 3014 \mathrm{E}$ & 1901S2830E & 52704804 & Unknown & Unknown & Unknown \\
\hline & Purple Heron (Ardea purpurea) & 0.00 & $3403 S 1829 E$ & $3403 \mathrm{~S} 1829 \mathrm{E}$ & 793605 & Pullus & Pullus & Unknown \\
\hline & Great Egret (Egretta alba) & 56.73 & $2015 S 3100 E$ & 2003S3030E & 824263 & Pullus & Unknown & Unknown \\
\hline & \multirow[t]{3}{*}{ Little Egret (Egretta garzetta) } & 1766.74 & $3404 \mathrm{~S} 1830 \mathrm{E}$ & $2502 S 3334 \mathrm{E}$ & 55505305 & Juvenile & Unknown & Unknown \\
\hline & & 147.23 & $3404 \mathrm{~S} 1830 \mathrm{E}$ & $3432 S 2000 \mathrm{E}$ & 55403748 & Pullus & Adult & Unknown \\
\hline & & 127.34 & $3404 \mathrm{~S} 1830 \mathrm{E}$ & 3300S1900E & 52402641 & Pullus & Unknown & Unknown \\
\hline & \multirow[t]{3}{*}{ Yellow-billed Egret (Egretta intermedia) } & $2143.67 \pm 15$ & $3404 \mathrm{~S} 1830 \mathrm{E}$ & $1515 S 2309 \mathrm{E}$ & 55501389 & Pullus & Unknown & Unknown \\
\hline & & 1379.00 & $2508 \mathrm{~S} 2822 \mathrm{E}$ & $3405 S 1828 \mathrm{E}$ & A02395 & Adult & Adult & Female \\
\hline & & 150.10 & $3404 \mathrm{~S} 1830 \mathrm{E}$ & $3432 S 2002 E$ & 55406280 & Juvenile & Adult & Unknown \\
\hline & \multirow[t]{3}{*}{ Cattle Egret (Bubulcus ibis) } & $4233.19 \pm 5$ & $2725 S 2710 E$ & 1028 N2317E & 644157 & Pullus & Unknown & Unknown \\
\hline & & $3762.16 \pm 5$ & $2936 S 3023 E$ & 0409N2754E & 54309342 & Pullus & Adult & Unknown \\
\hline & & 3491.00 & $2611 S 2817 \mathrm{E}$ & $0436 \mathrm{~N} 2154 \mathrm{E}$ & 58502523 & Pullus & Adult & Unknown \\
\hline & Squacco Heron (Ardeola ralloides) & $2294.85 \pm 350$ & 2918 S2958E & 0900S2600E & 55306426 & Pullus & Unknown & Unknown \\
\hline & \multirow{3}{*}{ Green-backed Heron (Butorides striata) } & 1.67 & $2535 S 2820 \mathrm{E}$ & $2535 S 2819 \mathrm{E}$ & 682810 & Adult & Adult & Unknown \\
\hline & & 0.00 & $2941 S 3104 \mathrm{E}$ & $2941 S 3104 \mathrm{E}$ & 614479 & $0.0-0.5$ year & Adult & Unknown \\
\hline & & 0.00 & $2941 S 3104 \mathrm{E}$ & $2941 S 3104 \mathrm{E}$ & 614472 & adult & Adult & Unknown \\
\hline & Black Heron (Egretta ardesiaca) & 469.16 & 2009S2836E & $1605 S 2725 \mathrm{E}$ & 58601664 & Juvenile & Unknown & Unknown \\
\hline & \multirow[t]{3}{*}{ Little Bittern (Ixobrychus minutus) } & 2.53 & $2116 S 2731 E$ & $2115 S 2732 \mathrm{E}$ & $5 A 01607$ & Adult & Adult & Male \\
\hline & & 0.00 & $2619 S 2721 E$ & $2619 S 2721 \mathrm{E}$ & 686354 & Adult & Adult & Unknown \\
\hline & & 0.00 & $2619 S 2721 E$ & $2619 S 2721 \mathrm{E}$ & PA14663 & Adult & Adult & Female \\
\hline & \multirow[t]{2}{*}{ Black-crowned Night-heron (Nycticorax nycticorax) } & 6995.78 & 4505 N2805E & $1730 S 3510 \mathrm{E}$ & H02801 (Romania) & Unknown & Adult & Unknown \\
\hline & & $1954.14 \pm 15$ & $2611 \mathrm{~S} 2818 \mathrm{E}$ & 0838S2720E & 729541 & Pullus & Unknown & Unknown \\
\hline \multirow[t]{14}{*}{ Ciconiidae } & \multirow[t]{3}{*}{ Marabou Stork (Leptoptilos crumeniferus) } & 1396.17 & $2612 \mathrm{~S} 3152 \mathrm{E}$ & 2933S1810E & G23668 & Pullus & Unknown & Unknown \\
\hline & & 1257.37 & $2612 S 3152 \mathrm{E}$ & $3341 S 2204 \mathrm{E}$ & G25335 & Pullus & Unknown & Unknown \\
\hline & & 523.00 & $2612 S 3152 \mathrm{E}$ & 2211S2910E & G23700 & Unknown & Unknown & Unknown \\
\hline & \multirow[t]{2}{*}{ African Openbill (Anastomus lamelligerus) } & 1174.31 & $1550 S 2721 \mathrm{E}$ & 1745S1630E & $1 \mathrm{~K} 00331$ & Pullus & Juvenile & Unknown \\
\hline & & 0.00 & 2017S2614E & 2017S2614E & 65703578 & Pullus & Unknown & Unknown \\
\hline & Woolly-necked Stork (Ciconia episcopus) & 2.45 & 2950S3050E & 2949S3051E & PS00864 & Adult & Adult & Unknown \\
\hline & \multirow[t]{3}{*}{ Abdim's Stork (Ciconia abdimii) } & 3021.58 & $1745 S 3110 E$ & 0415N1500E & 59703444 & Adult & Adult & Unknown \\
\hline & & $2329.01 \pm 5$ & 1750S3110E & $0303 \mathrm{~N} 2932 \mathrm{E}$ & 59701887 & Adult & Adult & Unknown \\
\hline & & $128.91 \pm 5$ & 1746S3105E & $1640 S 3042 \mathrm{E}$ & 732449 & Immature & Adult & Unknown \\
\hline & \multirow[t]{2}{*}{ Black Stork (Ciconia nigra) } & 4452.36 & 5015 N0622E & $1310 \mathrm{~N} 1208 \mathrm{~W}$ & DER AN653 (Denmark) & Pullus & $0.5-1.0$ year & r Unknown \\
\hline & & $50.36 \pm 5$ & $2033 S 2830 E$ & $2034 S 2801 E$ & 5260351 & Pullus & Unknown & Unknown \\
\hline & White Stork (Ciconia ciconia) & $10114.78 \pm 5$ & 5613N0959E & $3340 \mathrm{~S} 2624 \mathrm{E}$ & VIB00465 (Denmark) & Pullus & Adult & Unknown \\
\hline & & $10049.35 \pm 5$ & $5720 \mathrm{~N} 2528 \mathrm{E}$ & $330252700 \mathrm{E}$ & A143151 (Latvia) & Pullus & Juvenile & Male \\
\hline & & 10025.08 & 5613N2444E & $3348 \mathrm{~S} 1849 \mathrm{E}$ & 4920 (Lithuania) & Pullus & Adult & Unknown \\
\hline Threskiornithidae & African Sacred Ibis (Threskiornis aethiopicus) & $1465.87 \pm 5$ & 2800S2644E & 1516S2303E & 59702492 & Juvenile & Adult & Unknown \\
\hline & & 1451.54 & $2759 S 2642 \mathrm{E}$ & 1522S2305E & 59702497 & Pullus & Adult & Unknown \\
\hline & & 1335.37 & $2610 S 2826 \mathrm{E}$ & 1519S2255E & 52504862 & Pullus & Adult & Unknown \\
\hline & Southern Bald Ibis (Geronticus calvus) & 42.76 & $2655 S 3005 E$ & $270152940 \mathrm{E}$ & 864579 & Juvenile & Immature & Unknown \\
\hline & & 26.11 & $2647 S 3013 E$ & $265553000 \mathrm{E}$ & 812185 & Unknown & Adult & Unknown \\
\hline & & 11.00 & $270753008 \mathrm{E}$ & $2710 S 3002 E$ & 801548 & Pullus & Unknown & Unknown \\
\hline & Glossy Ibis (Plegadis falcinellus) & 1292.22 & $2611 S 2818 \mathrm{E}$ & $1539 \mathrm{~S} 2302 \mathrm{E}$ & 710061 & Pullus & Adult & Unknown \\
\hline & & $154.24 \pm 5$ & $2611 \mathrm{~S} 2818 \mathrm{E}$ & $2622 S 2646 \mathrm{E}$ & 710750 & Pullus & Adult & Unknown \\
\hline & & $75.19 \pm 5$ & $2611 \mathrm{~S} 2818 \mathrm{E}$ & 2554S2737E & 710599 & Pullus & Juvenile & Unknown \\
\hline & Hadeda Ibis (Bostrychia hagedash) & 148.07 & $3403 S 1826 \mathrm{E}$ & $3248 \mathrm{~S} 1753 \mathrm{E}$ & 878488 & Pullus & Adult & Unknown \\
\hline & & $91.56 \pm 15$ & $2606 S 2800 \mathrm{E}$ & $2520 S 2820 \mathrm{E}$ & 840407 & Unknown & Unknown & Unknown \\
\hline & & 67.00 & $3401 S 1827 \mathrm{E}$ & $3338 \mathrm{~S} 1901 \mathrm{E}$ & 871585 & Pullus & Unknown & Unknown \\
\hline & African Spoonbill (Platalea alba) & 1036.48 & $3254 \mathrm{~S} 1820 \mathrm{E}$ & $2645 S 2625 \mathrm{E}$ & 816817 & Pullus & Unknown & Unknown \\
\hline & & $1030.92 \pm 5$ & 2610 S2826E & $1731 S 2450 \mathrm{E}$ & 52501481 & Pullus & Juvenile & Unknown \\
\hline & & $790.44 \pm 5$ & 2017S2614E & 2723S2637E & 65700561 & Pullus & Unknown & Unknown \\
\hline
\end{tabular}

Note: Values displaying a \pm symbol indicate level of uncertainty because exact location was not known. Records belonging to foreign schemes are indicated in the ring number column in brackets. Initial Coord. refers to location of ringing and Second Coord. refers to the location where the individual was subsequently recovered. 


\section{Appendix 2}

TABLE 1-A2: Top three longevity records of southern African Ardeidae, Threskiornithidae and Ciconiidae species from ringing records at the South African Ringing Scheme.

\begin{tabular}{|c|c|c|c|c|c|c|c|c|}
\hline Family & Species & $\begin{array}{l}\text { Longevity } \\
\text { (days) }\end{array}$ & $\begin{array}{l}\text { Longevity } \\
\text { (years) }\end{array}$ & Initial date & Final date & Ring number & Initial age & Sex \\
\hline \multirow[t]{27}{*}{ Ardeidae } & \multirow[t]{3}{*}{ Grey Heron (Ardea cinerea) } & $4609 \pm 15$ & $12 y 7 m 13 d$ & $18-09-1951$ & 01-05-1964 & C01003 & Pullus & Unknown \\
\hline & & $4290 \pm 15$ & $11 y 8 m 30 d$ & 21-02-1974 & 20-11-1985 & 824278 & Pullus & Unknown \\
\hline & & 3160 & $8 y 7 m$ 24d & 07-04-1974 & 01-12-1982 & 903461 & Juvenile & Unknown \\
\hline & \multirow[t]{3}{*}{ Goliath Heron (Ardea goliath) } & 1683 & $4 y 7 m 8 d$ & 02-04-1975 & 10-11-1979 & G01804 & Pullus & Unknown \\
\hline & & 1554 & $4 y 3 m 1 d$ & 02-11-1968 & 03-02-1973 & 50801948 & Pullus & Unknown \\
\hline & & 1031 & $2 y 9 m 27 d$ & 19-08-1969 & $15-06-1972$ & 65804968 & Pullus & Unknown \\
\hline & \multirow{2}{*}{ Black-headed Heron (Ardea melanocephala) } & 6799 & $18 \mathrm{y} 7 \mathrm{~m} \mathrm{12d}$ & 03-11-1969 & $15-06-1988$ & 64604643 & Pullus & Unknown \\
\hline & & 6559 & $17 y 11 \mathrm{~m} 16 \mathrm{~d}$ & 28-11-1969 & 13-11-1987 & 64604922 & Pullus & Unknown \\
\hline & Purple Heron (Ardea purpurea) & 20 & Oy 0m 20d & $11-11-2003$ & $01-12-2003$ & 793605 & Pullus & Unknown \\
\hline & Squacco Heron (Ardeola ralloides) & 387 & $1 y 0 m 21 d$ & 09-12-1959 & $30-12-1960$ & 55306426 & Pullus & Unknown \\
\hline & \multirow[t]{3}{*}{ Cattle Egret (Bubulcus ibis) } & $8523 \pm 3$ & $23 y 4 m 2 d$ & 08-01-1966 & $10-05-1989$ & 64500592 & Pullus & Unknown \\
\hline & & 6753 & $18 y 5 m 27 d$ & 06-01-1974 & 03-07-1992 & 644700 & Pullus & Unknown \\
\hline & & $5920 \pm 15$ & $16 y 2 m 15 d$ & 08-11-1957 & 23-01-1974 & 55303890 & Unknown & Unknown \\
\hline & \multirow{2}{*}{ Green-backed Heron (Butorides striata) } & 546 & 1y $5 \mathrm{~m} \mathrm{28d}$ & 01-03-1992 & 29-08-1993 & 614472 & Adult & Unknown \\
\hline & & 367 & 1y $0 \mathrm{~m} 1 \mathrm{~d}$ & $18-01-2012$ & $19-10-2013$ & PA14151 & Adult & Unknown \\
\hline & Great Egret (Egretta alba) & $621 \pm 15$ & $1 y 8 m 14 d$ & 21-02-1974 & 04-11-1975 & 824263 & Pullus & Unknown \\
\hline & \multirow[t]{3}{*}{ Yellow-billed Egret (Egretta intermedia) } & 3626 & $9 y 11 \mathrm{~m} \mathrm{11d}$ & 20-11-1951 & $24-10-1961$ & D00232 & Pullus & Unknown \\
\hline & & 2155 & $5 y 10 m 25 d$ & 19-10-1956 & $13-09-1962$ & 55501312 & Unknown & Unknown \\
\hline & & 1532 & $4 y 2 \mathrm{~m} 10 \mathrm{~d}$ & 26-11-1957 & 05-02-1962 & 55403937 & Unknown & Unknown \\
\hline & Black Heron (Egretta ardesiaca) & 0 91 & $0 y 2 m 30 d$ & 16-03-1969 & $15-06-1969$ & 58601664 & Juvenile & Unknown \\
\hline & \multirow[t]{3}{*}{ Little Egret (Egretta garzetta) } & 3616 & $9 y 10 m 24 d$ & 18-11-1954 & $12-10-1964$ & 52500273 & Unknown & Unknow \\
\hline & & $3368 \pm 15$ & $9 y 2 \mathrm{~m} \mathrm{20d}$ & 26-10-1957 & $15-01-1967$ & 55403748 & Adult & Unknow \\
\hline & & 2094 & $5 y 8 m 26 d$ & 28-11-1953 & 23-08-1959 & 52400480 & Unknown & Unknown \\
\hline & \multirow[t]{3}{*}{ Little Bittern (Ixobrychus minutus) } & 2471 & $6 y 9 m 6 d$ & 23-01-2010 & 29-10-2016 & PA14663 & $1.0-2.0$ year & Female \\
\hline & & 1043 & $2 y 10 m 6 d$ & $17-03-2007$ & 23-01-2010 & 686354 & adult & Unknown \\
\hline & & 994 & $2 y 8 m 19 d$ & 23-04-2011 & $11-01-2014$ & PA11368 & $0.5-1.0$ year & Male \\
\hline & Black-crowned Night-heron (Nycticorax nycticorax) & $3931 \pm 15$ & $10 y 9 m 5 d$ & $17-10-1953$ & $22-07-1964$ & 52400899 & Unknown & Unknown \\
\hline \multirow[t]{15}{*}{ Threskiornithidae } & \multirow[t]{3}{*}{ Hadeda Ibis (Bostrychia hagedash) } & 3793 & $10 y 4 m 21 d$ & 20-02-1989 & 11-07-1999 & 836378 & Juvenile & Unknow \\
\hline & & 3294 & $9 y 0 m 7 d$ & 20-02-1989 & 27-02-1998 & 836385 & Juvenile & Unknow \\
\hline & & 3150 & $8 y 7 m$ 20d & $24-08-2007$ & 08-04-2016 & 871610 & Pullus & Unknow \\
\hline & \multirow[t]{3}{*}{ Southern Bald Ibis (Geronticus calvus) } & $1981 \pm 15$ & $5 y 5 m 4 d$ & $11-11-1972$ & $15-04-1978$ & 812185 & Unknown & Unknow \\
\hline & & 317 & Oy $10 \mathrm{~m} \mathrm{13d}$ & 01-12-2006 & $14-10-2007$ & 864579 & Juvenile & Unknow \\
\hline & & 101 & 0y $3 m 9 d$ & $16-10-2004$ & 25-01-2005 & 801548 & Pullus & Unknown \\
\hline & \multirow[t]{3}{*}{ African Spoonbill (Platalea alba) } & 5142 & $14 y 0 m 28 d$ & $17-10-1970$ & $14-11-1984$ & 903022 & Pullus & Unknow \\
\hline & & 4937 & $13 y 6 m 7 d$ & $14-11-1970$ & 21-05-1984 & 812729 & Pullus & Unknow \\
\hline & & 4388 & $12 y 0 m 5 d$ & $30-11-1974$ & $05-12-1986$ & 904691 & Pullus & Unknow \\
\hline & \multirow[t]{3}{*}{ Glossy Ibis (Plegadis falcinellus) } & 4684 & $12 y 9 m 27 d$ & $15-01-1972$ & $11-11-1984$ & 710750 & Pullus & Unknow \\
\hline & & 1644 & $4 y 6 m 4 d$ & 04-03-1972 & 03-09-1976 & 728940 & Pullus & Unknow \\
\hline & & $1292 \pm 180$ & $2 y 8 m 28 d$ & 21-11-1970 & $15-08-1973$ & 710061 & Pullus & Unknow \\
\hline & \multirow[t]{3}{*}{ African Sacred Ibis (Threskiornis aethiopicus) } & 7707 & $21 \mathrm{y} 1 \mathrm{~m} 6 \mathrm{~d}$ & $20-12-1952$ & 26-01-1974 & 52601770 & Unknown & Female \\
\hline & & 5845 & $16 y 0 m 1 d$ & 20-10-1956 & 21-10-1972 & 52500494 & Unknown & Unknown \\
\hline & & 5692 & $15 y 7 m$ Od & 04-03-1972 & 04-10-1987 & 58602786 & Unknown & Unknown \\
\hline \multirow[t]{8}{*}{ Ciconiidae } & African Openbill (Anastomus lamelligerus) & 169 & 0y $5 \mathrm{~m} \mathrm{16d}$ & $30-07-1974$ & $15-10-1975$ & $1 \mathrm{~K} 00331$ & Pullus & Unknow \\
\hline & & 37 & Oy $1 \mathrm{~m} 7 \mathrm{~d}$ & 21-04-1974 & $28-05-1974$ & 65703578 & Pullus & Unknow \\
\hline & Abdim's Stork (Ciconia abdimii) & 3319 & $9 y 1 \mathrm{~m} 1 \mathrm{~d}$ & 11-01-1967 & $12-02-1976$ & 59701887 & Unknown & Unknow \\
\hline & & 3318 & $9 y 0 m$ 30d & 06-01-1976 & 05-02-1985 & 732449 & Immature & Unknow \\
\hline & & 95 & $0 y 3 m 4 d$ & 24-01-1968 & $28-04-1968$ & 59703444 & Unknown & Unknown \\
\hline & White Stork (Ciconia ciconia) & 9238 & $25 y 3 m ~ 14 d$ & $25-06-1979$ & 09-10-2004 & $\begin{array}{l}16 \text { (Germany, } \\
\text { Helgoland) }\end{array}$ & Pullus & Unknown \\
\hline & & 8326 & $22 y 9 m 17 d$ & $17-06-1975$ & 03-04-1998 & $\begin{array}{l}\text { K00899 (Germany, } \\
\text { Hiddensee) }\end{array}$ & Pullus & Unknown \\
\hline & & $7314 \pm 3$ & $20 \mathrm{y} 0 \mathrm{~m} \mathrm{14d}$ & 29-06-1963 & $08-07-1983$ & $\begin{array}{l}\text { H07579 (Germany, } \\
\text { Helgoland) }\end{array}$ & Pullus & Unknown \\
\hline
\end{tabular}


TABLE 1-A2 (Continues...): Top three longevity records of southern African Ardeidae, Threskiornithidae and Ciconiidae species from ringing records at the South African Ringing Scheme.

\begin{tabular}{|c|c|c|c|c|c|c|c|c|}
\hline Family & Species & $\begin{array}{c}\text { Longevity } \\
\text { (days) }\end{array}$ & $\begin{array}{c}\text { Longevity } \\
\text { (years) }\end{array}$ & Initial date & Final date & Ring number & Initial age & Sex \\
\hline & \multirow[t]{2}{*}{ Woolly-necked Stork (Ciconia episcopus) } & 243 & Oy $8 \mathrm{~m} \mathrm{Od}$ & $29-12-2014$ & 29-08-2015 & PS00864 & Adult & Unknown \\
\hline & & 119 & $0 y 3 m 29 d$ & 29-12-2014 & 27-04-2015 & PS00864 & Adult & Unknown \\
\hline & \multirow[t]{2}{*}{ Black Stork (Ciconia nigra) } & $1083 \pm 15$ & $2 y 11 m 18 d$ & 28-08-1965 & $15-08-1968$ & 52600351 & Unknown & Unknown \\
\hline & & 263 & $0 y 8 m 18 d$ & $15-06-2014$ & 05-03-2015 & $\begin{array}{l}\text { DER AN653 } \\
\text { (Denmark) }\end{array}$ & Pullus & Unknown \\
\hline & \multirow[t]{2}{*}{ Marabou Stork (Leptoptilos crumeniferus) } & $2883 \pm 15$ & $7 y 10 m 23 d$ & $26-09-2008$ & $18-08-2016$ & G25906 & Pullus & Unknown \\
\hline & & 1184 & 3у $2 \mathrm{~m} \mathrm{27d}$ & $25-08-2011$ & $21-11-2014$ & S162 & Pullus & Unknown \\
\hline
\end{tabular}

Note: Values displaying a \pm symbol indicate level of uncertainty because exact date was not known. Records belonging to foreign schemes are indicated in the ring number column in brackets. $y$, years; $m$, months; $d$, days 